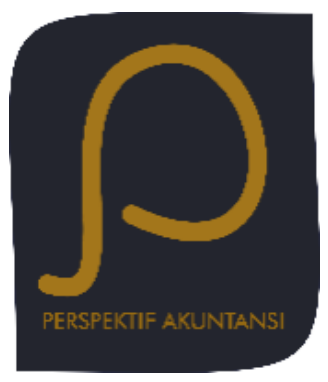

Perspektif Akuntansi Volume 4 Nomor 2 (Juni 2021), hal. 145-173 ISSN: 2623-0194 (Print), 2623-0186 (Online) Copyright(C The Authors(s). All Rights Reserved Center for Accounting Development and Research (CARD)

Fakultas Ekonomika dan Bisnis,

Universitas Kristen Satya Wacana

DOI: https://doi.org/10.24246/persi.vXiX.p145-173 http://ejournal.uksw.edu/persi

\title{
Persepsi Keadilan dan Kepatuhan Pajak pada Wajib Pajak Pengusaha dan Pekerja di Kota Salatiga
}

\author{
Ferry Ayu Wardani ${ }^{1}$ \\ CV. Primastar, Semarang
}

Received

05/04/2021

Abstract. The purpose of this research is to provide a description of the perception of tax fairness and tax compliance on taxpayer businessmen and employee in city Salatiga. The samples of this

Revised

$30 / 06 / 2021$

Accepted

$30 / 06 / 2021$ research are businessmen and employees in Salatiga city which is using accidental sampling technique to choose the sample with. The data used in this research is primary data which was obtained directly from the respondents with questionnaire method. The method used in this research is descriptive statistic and t-test with $5 \%$ significance level. The results of this research indicate that (1) generally there is no difference in perception between businessmen and employees in dimensions of general fairness, exchange with the government, special provisions, tax-rate structure and self interest (2) employeess are more than compliance compared businessmen with with holding tax system.

Keywords: tax fairness, tax compliance 


\begin{abstract}
Abstrak. Tujuan penelitian ini adalah untuk memberikan deskripsi persepsi keadilan dan kepatuhan pajak pada wajib pajak pengusaha dan pekerja di kota Salatiga. Sampel dalam penelitian ini adalah pengusaha dan pekerja yang berada di kota Salatiga dengan pengambilan sampel menggunakan teknik accidental sampling. Jenis data dalam penelitian ini adalah data primer yang diperoleh langsung dari responden menggunakan metode kuesioner. Metode penelitian yang digunakan dalam penelitian ini adalah statistik deskriptif dan uji-t dengan tingkat signifikansi 5\%. Hasil dari penelitian ini menunjukan bahwa (1) secara umum tidak terdapat perbedaan persepsi antar kelompok pengusaha dan pekerja pada dimensi keadilan umum, timbal balik pemerintah, ketentuan-ketentuan khusus, struktur tarif pajak dan kepentingan pribadi (2) Kelompok pekerja lebih patuh pajak dibanding kelompok pengusaha dengan pengenaan pajak with holding tax system.
\end{abstract}

Kata kunci: keadilan pajak, kepatuhan pajak.

\title{
Pendahuluan
}

Pembangunan nasional dilakukan secara terus menerus dalam upaya peningkatan kesejahteraan masyarakat. Salah satu aliran dana yang menyokong pembangunan adalah dari sektor perpajakan. Pendapatan perpajakan sebagai sumber dana yang diperuntukkan bagi pembiayaan pengeluaran-pengeluaran pemerintah, sebagai alat untuk mengatur atau melaksanakan kebijakan di bidang sosial dan ekonomi (Hardiningsih dan Yulianawati, 2011). Kebijakan pemerintah dalam mengambil keputusan pembangunan infrastruktur maupun layanan publik bergantung pada besarnya pendapatan pajak. Ketika kemampuan pemerintah dalam mengumpulkan pendapatan pajak rendah, maka kapasitas untuk penyediaan barang dan layanan akan terganggu (Gilligan dan Richardson, 2005).

Realisasi pendapatan pajak oleh Direktorat Jendral Pajak (DJP) untuk tahun ke tahun terus mengalami peningkatan, namun belum mencapai jumlah yang ditargetkan. Berikut data target dan realisasi penerimaan pajak untuk tahun 2013 sampai dengan tahun 2016 ditampilkan dalam Tabel 1 sebagai berikut.

\section{Tabel 1. Target dan Realisasi penerimaan pajak}

\begin{tabular}{cccc}
\hline Tahun & $\begin{array}{c}\text { Target ( Triliun } \\
\text { Rupiah) }\end{array}$ & $\begin{array}{c}\text { Realisasi ( Triliun } \\
\text { Rupiah) }\end{array}$ & $\begin{array}{c}\text { Persentase } \\
\text { (\%) }\end{array}$ \\
\hline 2013 & $1.148,3$ & $1.077,3$ & 93 \\
2014 & $1.246,1$ & $1.146,9$ & 92 \\
2015 & $1.489,3$ & $1.240,4$ & 83,3 \\
2016 & $1.539,2$ & $1.285,0$ & 83,5 \\
\hline
\end{tabular}

Sumber: Kementrian Keuangan Republik Indonesia (2017) 
Penerimaan negara dari sektor perpajakan, salah satunya dapat ditentukan oleh tingkat kepatuhan masyarakat terhadap pembayaran pajak. Penelitian Suhendra (2010) mengemukakan bahwa tingkat kepatuhan wajib pajak berpengaruh positif terhadap peningkatan penerimaan pajak. Semakin patuh wajib pajak dalam melaporkan dan melunasi kewajiban perpajakannya, maka akan meningkatkan pendapatan pajak. Sebaliknya, semakin banyak wajib pajak yang tidak patuh pajak, dalam arti menggelapkan atau melakukan tindak kecurangan pajak, maka semakin rendah tingkat pendapatan pajak negara.

Tingkat kepatuhan pajak wajib pajak dapat dibentuk dari persepsi setiap wajib pajak mengenai keadilan sistem pajak. Ketika persepsi masyarakat tentang pajak negatif, maka dapat diikuti adanya penurunan tingkat kepatuhan pajak. Namun, ketika persepsi wajib pajak terhadap pajak positif, maka tingkat kepatuhan wajib pajak akan meningkat. Semakin baik persepsi keadilan sistem pajak, maka semakin tinggi pula kepatuhan wajib pajak (Witono, 2008).

Wajib pajak di Indonesia beragam karakteristiknya, dapat dilihat dari karakteristik wajib pajak pengusaha dan pekerja dengan sistem pengenaan pajak yang berbeda. Pengenaan pajak pada wajib pajak pengusaha sebagian besar menggunakan self assessment system, dengan sebagian besar keputusan berperilaku patuh maupun tidak patuh ada di tangan wajib pajak. Sedangkan, bagi wajib pajak pekerja sebagian besar pengenaan pajaknya menggunakan withholding tax system ketika hanya sebagian kecil keputusan untuk berperilaku patuh atau tidak patuh yang ada di tangan wajib pajak. Hal ini disebabkan sebagian besar penghasilan wajib pajak pekerja pada umumnya diperoleh dari pemberi kerja yang pengenaan pajaknya merupakan with holding tax. Perbedaan karakteristik kelompok wajib pajak pengusaha dan pekerja yang disertai dengan perbedaan peraturan undang-undang pajak penghasilan yang berlaku, menarik untuk dipelajari bagaimana persepsi keadilan pajak antar kelompok wajib pajak. Dan dengan adanya tingkat keputusan berperilaku patuh yang berbeda antar wajib pajak pengusaha dan pekerja, menarik untuk diteliti apakah adanya persamaan tingkat kepatuhan antar kelompok dengan perbedaan tingkat keputusan berperilaku patuh. Dengan tingkat keputusan berperilaku patuh/tidak patuh yang rendah pada kelompok pekerja dapat dipelajari apakah adanya aspek perilaku tidak patuh pajak.

Berdasarkan latar belakang di atas, maka perlu diteliti bagaimana persepsi keadilan dengan kepatuhan pajak pada wajib pajak pengusaha dan pekerja. Tujuan dari penelitian ini adalah untuk memberikan deskripsi persepsi keadilan dan kepatuhan pada wajib pajak pengusaha dan pekerja yang berada di kota Salatiga. Penelitian kali ini diharapkan dapat dipakai untuk memahami apakah ada perbedaan persepsi mengenai keadilan dan kepatuhan pajak pada kelompok wajib pajak dengan karakteristik yang berbeda. Penelitian sebelumnya pernah dilakukan mengenai persepsi keadilan dan kepatuhan pajak di Australia dan Hong Kong dengan garis budaya yang berbeda (Gilligan dan Richarson, 2005). Hasil penelitian menyatakan bahwa adanya perbedaan persepsi keadilan dan kepatuhan pajak masyarakat Australia dan Hong Kong. Namun, penelitian sebelumnya belum mengidentifikasi persepsi yang mengenai keadilan dan kepatuhan pajak antar kelompok wajib pajak 
yang berbeda. Oleh karenanya, penelitian kali ini mereplikasi penelitian (Gilligan dan Richarson, 2005) mengenai persepsi keadilan dan kepatuhan pajak dengan objek kelompok wajib pajak pengusaha dan pekerja dengan karakteristik pengenaan sistem pajak yang berbeda. Studi sebelumnya meneliti perbedaan persepsi keadilan dan kepatuhan pajak pada dua kelompok wajib pajak berdasarkan yurisdiksi hukum negara yang berbeda, yaitu Australia dan Hongkong. Perbedaan yurisdiksi hukum akan juga berperan dalam membentuk perbedaan peraturan perpajakan di negara masing-masing, sehingga terdapat celah ketika sebenarnya kedua kelompok yang sudah diteliti terpapar oleh lingkungan perpajakan yang berbeda. Penelitian kali ini hendak menutup celah tersebut, hanya dengan berfokus pada setting satu negara yaitu Indonesia, untuk mengeliminasi perbedaan persepsi wajib pajak yang memang berkaitan dengan seting negara yang berbeda. Secara spesifik, penelitian kali ini akan mendeskripsikan persepsi antar kelompok dengan seting negara Indonesia, namun dipungut pajak dengan cara yang berbeda.

Penelitian ini diharapkan dapat memberikan manfaat bagi DJP untuk memberikan informasi bagaimana persepsi keadilan dan kepatuhan pajak pada wajib pajak pengusaha dan pekerja, sehingga dapat menjadi salah satu masukan dalam mengambil kebijakan upaya meningkatkan kepatuhan pajak. Hasil penelitian ini juga akan memperkaya pemahaman mengenai penelitian di bidang keadilan dan kepatuhan pajak, sehingga menjadi referensi bagi peneliti selanjutnya.

\section{Telaah Pustaka}

\section{Keadilan Pajak}

Adil berarti sama berat, tidak berat sebelah dan tidak memihak. Keadilan pajak adalah sifat (perbuatan atau perlakuan) yang tidak sewenang-wenang atau tidak berat sebelah atas sistem perpajakan yang berlaku (Pris, 2010). Keadilan pajak dapat membentuk bagaimana persepsi wajib pajak terhadap sistem pajak. Sedangkan, persepsi keadilan pajak merupakan suatu penafsiran untuk menginterpretasikan keadilan pada sistem pajak. Ketika adanya keadilan dalam sistem pajak, maka akan muncul persepsi positif terhadap sistem pajak. Namun, ketika adanya ketidakadilan dalam sistem pajak, maka akan muncul persepsi negatif terhadap sistem pajak. Gerbing (1988) dalam Gilligan dan Richardson (2005) mengungkapkan lima dimensi dasar keadilan pajak, yaitu: keadilan umum, timbal balik pemerintah, ketentuanketentuan khusus, struktur tarif pajak dan keadilan pribadi.

\section{Keadilan Umum}

Keadilan umum merupakan keadaan saat wajib pajak merasakan adanya pembebanan pajak yang sebanding dengan penghasilan atau kemampuan wajib pajak dalam membayar beban pajak. Keadilan umum dapat dirasakan pula ketika adanya kebijakan yang dibuat dengan adil tanpa manipulasi oleh petugas pajak. Ketika wajib pajak merasakan adanya keadilan dalam pembebanan pajak maupun kebijakan yang berlaku, akan membentuk persepsi bahwa pajak adalah sesuatu yang tidak memberatkan dan adil. Namun, ketidakseimbangan antara beban pajak dengan pendapatan dan adanya manipulasi dalam proses pembayaran pajak, dapat 
mempengaruhi tingkat kepercayaan wajib pajak terhadap sistem pajak yang membentuk persepsi bahwa adanya ketidakadilan sistem pajak. Sehingga, setiap kebijakan dan peraturan perpajakan yang berlaku antar kelompok wajib pajak akan membentuk bagaimana persepsi dari setiap kelompok atau wajib pajak mengenai keadilan umum sistem perpajakan. Hasil penelitian Gilligan dan Richardson (2005) menyatakan bahwa ada perbedaan persepsi keadilan umum antara Australia dan Hong Kong.

\section{Timbal Balik Pemerintah}

Dimensi timbal balik dengan pemerintah berkaitan dengan manfaat yang diterima sebagai imbalan timbal balik atas pembayaran pajak. Dalam proses pembayaran pajak masyarakat berharap adanya timbal balik dari pemerintah disertai peningkatan kesejahteraan dengan fasilitas yang diberikan pemerintah dalam bentuk proses kesinambungan terhadap penyediaan layanan publik serta perbaikan birokrasi. Ketika masyarakat merasa manfaat berupa timbal balik yang mereka terima wajar dan sebanding dengan besarnya pajak yang mereka bayarkan, akan membentuk persepsi bahwa timbal balik yang mereka diterima sudah adil. Namun, ketika masyarakat merasa manfaat yang diterima tidak wajar dan tidak sesuai jika dibandingkan dengan besarnya pajak yang dibayarkan, akan membentuk persepsi bahwa timbal balik pemerintah yang mereka diterima tidak adil. Sehingga, wajar dan tidak wajarnya manfaat yang diterima antar wajib pajak sebagai imbalan pembayaran pajak akan membentuk bagaimana persepsi dari setiap kelompok atau wajib pajak mengenai keadilan timbal balik pemerintah. Hasil penelitian Gilligan dan Richardson (2005) menyatakan bahwa tidak adanya perbedaan persepsi timbal balik pemerintah antara Australia dan Hong Kong.

\section{Ketentuan-Ketentuan Khusus}

Dimensi ketentuan-ketentuan khusus berkaitan dengan ketentuan khusus yang ditetapkan oleh pemerintah yang diberikan kepada wajib pajak tertentu. Ketentuan khusus yang ditetapkan oleh pemerintah dapat menimbulkan gap, karena hanya dapat digunakan oleh wajib pajak tertentu. Celah penelitian yang ada memicu munculnya paradigma bahwa pemerintah hanya peduli kepada wajib pajak tertentu. Ketika wajib pajak merasa bahwa ketentuan yang ditetapkan pemerintah hanya memihak pada kelompok tertentu yang menyebabkan ketimpangan pengenaan beban pajak, akan menimbulkan persepsi tidak adil pada ketentuan khusus yang berlaku. Namun, ketika ketentuan khusus yang ditetapkan pemerintah dirasa untuk kepentingan bersama, masyarakat dapat mentoleransi dan menganggap bahwa ketentuan khusus yang berlaku adalah adil. Atas dasar tersebut, setiap ketentuan khusus yang berlaku antar kelompok wajib pajak akan membentuk bagaimana persepsi dari setiap kelompok atau wajib pajak mengenai keadilan ketentuanketentuan khusus yang ada. Hasil penelitian Gilligan dan Richardson (2005) menunjukkan bahwa adanya perbedaan persepsi ketentuan ketentuan khusus antara Australia dan Hong Kong. 


\section{Struktur Tarif Pajak}

Dimensi Struktur tarif pajak berkaitan dengan struktur tarif pajak yang lebih disukai dan berlaku disuatu negara. Ketika struktur tarif pajak yang berlaku antar kelompok maupun wajib pajak perhitungan pembebanan pajaknya tidak sesuai dengan penghasilan, maka akan membentuk persepsi bahwa struktur tarif pajak yang berlaku tidak adil. Namun, ketika struktur tarif pajak yang berlaku mencerminkan kemampuan membayar (ability to pay) akan muncul persepsi bahwa struktur pajak yang berlaku adil. Sehingga, struktur tarif pajak yang berlaku antar kelompok wajib pajak akan membentuk bagaimana persepsi dari setiap kelompok maupun wajib pajak mengenai keadilan struktur tarif pajak. Hasil penelitian Gilligan dan Richardson (2005) menunjukkan bahwa adanya perbedaan persepsi struktur tarif pajak antara Australia dan Hong Kong.

\section{Kepentingan Pribadi}

Dimensi kepentingan pribadi berkaitan dengan perbandingan pembayaran pajak terhadap lingkungan sekitar, yaitu perbandingan jumlah pajak yang telah dibayarkan dengan jumlah pajak yang dibayarkan oleh wajib pajak lain. Wajib pajak akan merasa adanya keadilan kepentingan pribadi ketika adanya kesebandingan pajak yang dibayarkan sesuai dengan jumlah beban pajak yang dibayarkan oleh wajib pajak lain. Namun, ketika adanya fenomena bahwa masyarakat berpenghasilan sama atau lebih tidak jujur dalam pembayaran pajak akan menimbulkan persepsi tidak sebanding, dan dapat membuat persepsi ketidakadilan kepentingan pribadi. Selanjutnya, fenomena yang terjadi pada lingkungan antar kelompok wajib pajak akan membentuk bagaimana persepsi dari setiap kelompok maupun wajib pajak mengenai keadilan kepentingan pribadi perpajakan. Hasil penelitian Gilligan dan Richardson (2005) menunjukkan bahwa ada perbedaan persepsi kepentingan pribadi antara Australia dan Hong Kong.

\section{Kepatuhan Pajak}

Kepatuhan pajak adalah perilaku wajib pajak yang tepat waktu dan patuh terhadap peraturan serta ketentuan pajak yang berlaku di suatu Negara. Perilaku patuh dan tidak patuh pada sistem pajak yang berlaku didorong oleh persepsi wajib pajak terhadap keadilan dan kebenaran dari sistem pajak. Ketika wajib pajak merasa tidak adanya keadilan dan kebenaran sistem pajak dapat menimbulkan persepsi negatif terhadap pajak yang membentuk perilaku kepatuhan pajak. Ketidakpatuhan pajak yang terjadi mungkin tidak disengaja akibat ketidaktahuan, kebingungan dan kesalahan dengan kesengajaan penghindaran pajak. Hal ini, akan mengakibatkan kepatuhan sistem pajak akan semakin rendah dan percaya bahwa ketidakpatuhan adalah hal biasa yang terjadi dan dapat diterima.

Peningkatan kepatuhan pajak diupayakan oleh pemerintah melalui berbagai upaya, termasuk desain sistem pemungutan pajak. Pada awalnya, pemungutan pajak banyak didasarkan pada official assessment system. Dalam sistem ini, negara memiliki peran sentral dalam menghitung serta memungut pajak dari warga negara. Sejak reformasi perpajakan, Indonesia lebih banyak menganut self assessment system, wajib pajak 
diberikan kewenangan untuk menghitung, menyetor dan melaporkan pajaknya sendiri-sendiri. Selain itu, juga berkembang withholding system, saat pihak ke-tiga yang dibebani tanggung jawab untuk memungut pajak.

Dalam konteks saat ini, wajib pajak orang pribadi di Indonesia terbagi menjadi dua kelompok besar, yakni mereka yang wajib menghitung sendiri kewajiban pajaknya (yaitu pengusaha dan pekerja bebas), serta mereka yang murni kewajiban pajaknya sudah dipenuhi oleh pihak ke-tiga (pegawai). Perbedaan mekanisme pemungutan pajak ini menjadi basis yang dapat membedakan persepsi kedua kelompok ini terhadap keadilan dan kepatuhan pajak, karena mereka memenuhi kewajiban pajak dengan cara yang berbeda. Pengusaha dan pekerja bebas yang memenuhi kewajiban pajak dengan basis self assessment system dapat memiliki motif untuk melakukan penghindaran pajak. Namun demikian, untuk kelompok wajib pajak orang pribadi yang penghasilannya murni dari gaji pegawai, maka tidak ada motif untuk melakukan penghindaran pajak, sebab kewajiban pajaknya diselesaikan dengan withholding system.

Dalam penelitian Yankelovich et al., (1984) menjelaskan bahwa kepatuhan pajak dapat diukur dari sikap (attitude) dan perilaku yang dilaporkan. Fenomena yang terjadi dalam penelitian ini menjelaskan adanya sikap meremehkan dan tidak peduli terhadap pembayaran pajak yang didukung obyek kecurangan. Tujuan penelitian ini adalah memprediksi kepatuhan pajak masyarakat di Washington. Kepatuhan pajak yang diukur dari sikap (attitude) diukur dengan lima belas item kuesioner, enam item kuesioner tentang perilaku tidak patuh pajak dan sembilan item tentang berbagai alasan perilaku tidak patuh pajak.

\section{Metoda}

\section{Populasi dan Sampel}

Penelitian ini bersifat kuantitatif untuk memberikan deskripsi bagaimana persepsi keadilan dan kepatuhan pajak dengan karakteristik yang berbeda (wajib pajak pengusaha dan pekerja). Populasi dari penelitian ini adalah wajib pajak pengusaha dan pekerja yang ada di Salatiga. Sampel dalam penelitian ini adalah wajib pajak pengusaha dan pekerja di kota Salatiga dengan kriteria memiliki NPWP. Dalam pengambilan sampel peneliti menggunakan teknik accidental sampling yaitu pengambilan sampel berdasarkan kebetulan atau tidak disengaja bertemu dengan peneliti dan sesuai dengan kriteria (ciri-ciri) yang ditentukan. Kelebihan dari teknik accidental sampling adalah sampel mudah didapat. Dalam menentukan ukuran sampel Roscoe (1975) memberikan pedoman yaitu jika sampel dipecah lagi ke dalam subsampel jumlah sampel minimum harus 30. Maka, dalam penelitian kali ini peneliti mengambil 60 sampel, 30 sampel untuk wajib pajak pengusaha dan 30 sampel untuk wajib pajak pekerja.

\section{Data dan Sumber Data}

Jenis data yang digunakan dalam penelitian ini adalah data primer, yaitu data yang diperoleh secara langsung dari narasumber/responden. Sedangkan, untuk teknik 
pengambilan data menggunakan metode kuesioner yang bersumber dari pengusaha dan pekerja di Salatiga.

\section{Definisi Operasional dan Pengukuran Variabel}

\section{Keadilan umum}

Keadilan umum terkait dengan keadilan sistem perpajakan dan distribusi pembebanan pajak secara menyeluruh. Keadilan umum dikatakan adil atau tidak adil jika pajak yang dibebankan kepada wajib pajak sebanding atau tidak dengan penghasilan, dan ketika ada atau tidak adanya manipulasi dari petugas pajak.

\section{Timbal balik pemerintah}

Dimensi timbal balik dengan pemerintah berkaitan atas manfaat yang diterima sebagai imbalan timbal balik atas pembayaran pajak. Dimensi timbal balik dikatakan adil atau tidak adil dapat dilihat ketika ada atau tidak adanya perbaikan birokrasi dan penyediaan layanan publik.

\section{Ketentuan-Ketentuan Khusus}

Dimensi ini terkait ketika adanya ketentuan-ketentuan khusus yang ditetapkan oleh pemerintah dalam proses pembayaran pajak. Adil atau tidak adil ketentuan-khusus muncul ketika keadilan yang pemerintah tetapkan hanya berlaku bagi kelompok tertentu.

\section{Struktur Tarif Pajak}

Dimensi ini berkaitan dengan adanya struktur tarif pajak penghasilan yang berlaku. Struktur tarif pajak dikatakan adil atau tidak adil, dapat dengan struktur tarif yang memberatkan wajib pajak atau tidak.

\section{Kepentingan pribadi}

Dimensi kepentingan pribadi berhubungan dengan perbandingan lingkungan sekitar. Dimensi kepentingan pribadi dikatakan adil atau tidak adil dengan membandingkan jumlah beban pajak yang dibayarkan dengan jumlah pajak yang dibayarkan oleh wajib pajak lain. 
Tabel 2. Indikator Empiris Keadilan Pajak

\begin{tabular}{|c|c|}
\hline Indikator & Pernyataan \\
\hline \multicolumn{2}{|l|}{ Keadilan Umum (KU) } \\
\hline $\begin{array}{l}\text { Bagi wajib pajak pada umumnya, } \\
\text { sistem pajak di Indonesia diatur secara } \\
\text { adil (KU1) }\end{array}$ & $\begin{array}{l}\text { Masyarakat umum berpendapat bahwa } \\
\text { sistem pajak penghasilan di Indonesia } \\
\text { adalah adil }\end{array}$ \\
\hline $\begin{array}{l}\text { Sistem pajak penghasilan di Indonesia } \\
\text { diatur secara adil (KU2) }\end{array}$ & $\begin{array}{l}\text { Saya pribadi berpendapat bahwa sistem } \\
\text { pajak penghasilan di Indonesia adalah } \\
\text { adil }\end{array}$ \\
\hline $\begin{array}{l}\text { Cara pembebanan pajak } \\
\text { didistribusikan secara adil (KU3) }\end{array}$ & $\begin{array}{l}\text { Saya meyakini bahwa pendistribusian } \\
\text { cara perhitungan pajak antar kelompok } \\
\text { wajib pajak di Indonesia telah dilakukan } \\
\text { secara adil }\end{array}$ \\
\hline $\begin{array}{l}\text { Pajak penghasilan dibebankan secara } \\
\text { adil (KU4) }\end{array}$ & $\begin{array}{l}\text { Saya merasa bahwa pajak penghasilan } \\
\text { yang saya tanggung sudah adil }\end{array}$ \\
\hline $\begin{array}{l}\text { Beban pajak } \quad \text { penghasilan } \\
\text { didistribusikan secara adil (KU5) }\end{array}$ & $\begin{array}{l}\text { Saya meyakini bahwa besarnya beban } \\
\text { pajak penghasilan telah dibagi secara } \\
\text { adil kepada seluruh rakyat Indonesia. }\end{array}$ \\
\hline $\begin{array}{l}\text { Wajib pajak penghasilan menengah } \\
\text { kebawah membayar pajak lebih dari } \\
\text { beban pajak penghasilan (KU6) }\end{array}$ & $\begin{array}{l}\text { Menurut saya, kelompok masyarakat } \\
\text { ekonomi menengah kebawah membayar } \\
\text { pajak lebih dari porsi yang seharusnya } \\
\text { dibebankan. }\end{array}$ \\
\hline $\begin{array}{l}\text { Pembayaran beban pajak yang terlalu } \\
\text { tinggi (KU7) }\end{array}$ & $\begin{array}{l}\text { Menurut saya, porsi penerimaan pajak } \\
\text { pemerintah dari masyarakat ekonomi } \\
\text { menengah kebawah terlalu tinggi }\end{array}$ \\
\hline \multicolumn{2}{|l|}{ Timbal Balik Pemerintah (TB) } \\
\hline $\begin{array}{l}\text { Besarnya manfaat yang diterima dari } \\
\text { pembayaran pajak adalah sesuai dan } \\
\text { adil (TB1) }\end{array}$ & $\begin{array}{l}\text { Manfaat berupa timbal balik dari } \\
\text { pemerintah, saya nilai wajar/masuk akal. }\end{array}$ \\
\hline $\begin{array}{l}\text { Besarnya pembayaran pajak adalah } \\
\text { sesuai dan adil (TB2) }\end{array}$ & $\begin{array}{l}\text { Besarnya pajak penghasilan yang saya } \\
\text { bayar adalah wajar, jika dibanding } \\
\text { dengan manfaat/timbal-balik dari } \\
\text { pemerintah. }\end{array}$ \\
\hline $\begin{array}{l}\text { Pajak penghasilan yang dibayarkan } \\
\text { terlalu tinggi bila dibandingkan dengan } \\
\text { manfaat yang diterima (TB3) }\end{array}$ & $\begin{array}{l}\text { Beban pajak penghasilan yang saya } \\
\text { bayarkan terlalu tinggi bila } \\
\text { dibandingkan dengan manfaat yang } \\
\text { diberikan oleh pemerintah }\end{array}$ \\
\hline \multicolumn{2}{|l|}{ Ketentuan-Ketentuan Khusus (KK) } \\
\hline $\begin{array}{l}\text { Ketentuan-ketentuan khusus yang ada } \\
\text { tidak adil (KK1) }\end{array}$ & $\begin{array}{l}\text { Terdapat ketidakadilan berupa } \\
\text { ketentuan-ketentuan khusus yang hanya } \\
\text { dapat digunakan oleh wajib pajak } \\
\text { tertentu. }\end{array}$ \\
\hline $\begin{array}{l}\text { Pengurangan pajak yang hanya dapat } \\
\text { digunakan oleh wajib pajak } \\
\text { penghasilan tinggi adalah tidak adil } \\
\text { (KK2) }\end{array}$ & $\begin{array}{l}\text { Terdapat ketidakadilan berupa } \\
\text { pengurangan pajak yang hanya dapat } \\
\text { digunakan oleh wajib pajak penghasilan } \\
\text { tinggi. }\end{array}$ \\
\hline $\begin{array}{l}\text { Peraturan pajak penghasilan yang } \\
\text { berlaku saat ini (KK3) }\end{array}$ & $\begin{array}{l}\text { Peraturan pajak saat ini tidak menuntut } \\
\text { saya membayar lebih besar dari porsi } \\
\text { saya seharusnya. }\end{array}$ \\
\hline \multicolumn{2}{|l|}{ Struktur Tarif Pajak (ST) } \\
\hline $\begin{array}{l}\text { Tarif pajak yang lebih tinggi bagi orang } \\
\text { berpenghasilan tinggi (ST1) }\end{array}$ & $\begin{array}{l}\text { Orang berpenghasilan tinggi sudah } \\
\text { sepantasnya membayar pajak dengan } \\
\text { tarif lebih tinggi daripada orang } \\
\text { berpenghasilan rendah. }\end{array}$ \\
\hline
\end{tabular}


Masyarakat penghasilan tinggi Menurut saya, keadilan ada jika sewajarnya dibebani tarif pajak masyarakat penghasilan tinggi penghasilan lebih besar (ST2) dikenakan tarif pajak lebih tinggi dibanding masyarakat berpenghasilan lebih rendah.

Sistem tarif pajak proposional adalah Menurut saya, keadilan ada jika tarif adil (ST3) pajak dikenakan dengan persentase yang sama baik untuk orang berpenghasilan tinggi maupun rendah.

Pembayaran beban pajak oleh wajib Menurut saya total pajak penghasilan pajak penghasilan tinggi adalah wajar (ST4) yang dibayarkan oleh wajib pajak penghasilan tinggi adalah wajar.

\begin{tabular}{|c|c|}
\hline Kepentingan Pribadi (KP) & \\
\hline $\begin{array}{l}\text { Sistem perpajakan adalah sistem } \\
\text { terbaik untuk penerimaan pemerintah } \\
\text { (KP1) }\end{array}$ & $\begin{array}{l}\text { Sistem pengenaan pajak penghasilan } \\
\text { saat ini adalah sistem paling baik dalam } \\
\text { mengumpulkan penerimaan negara. }\end{array}$ \\
\hline $\begin{array}{l}\text { Perbandingan pembayaran pajak } \\
\text { dengan orang } \\
\text { besar (KP2) }\end{array}$ & $\begin{array}{l}\text { Dibandingkan dengan orang } \\
\text { berpendapatan lebih tinggi, saya merasa } \\
\text { membayar lebih dari porsi wajar saya }\end{array}$ \\
\hline $\begin{array}{l}\text { Membandingan pembayaran } \\
\text { dengan wajib pajak lain (KP3) }\end{array}$ & $\begin{array}{l}\text { Dibandingkan dengan wajib pajak } \\
\text { lainnya, saya membayar pajak sesuai } \\
\text { porsi saya seharusnya. }\end{array}$ \\
\hline
\end{tabular}

Sumber: Gerbing (1988) dalam Gilligan dan Richardson (2005)

\section{Kepatuhan Pajak}

Kepatuhan pajak merupakan perilaku wajib pajak yang tepat waktu dan patuh terhadap peraturan serta ketentuan pajak yang berlaku di suatu Negara. Ketika wajib pajak merasakan adanya ketidakadilan dan kebenaran sistem pajak dapat menimbulkan persepsi negatif terhadap pajak dan akan mempengaruhi perilaku kepatuhan pajak. Indikator menurut Yankeovich et al., (1984), dalam Gilligan dan Richardson (2005) yang berhubungan dengan kepatuhan pajak dan alasan perilaku ketidakpatuhan pajak adalah sebagai berikut tertera pada tabel 3: 
Tabel 3 Indikator Empiris Kepatuhan Pajak

\begin{tabular}{|c|c|}
\hline Indikator & Pernyataan \\
\hline \multicolumn{2}{|l|}{ Perilaku Tidak Patuh Pajak (TP) } \\
\hline $\begin{array}{l}\text { Tidak melaporkan di SPT ketika adanya } \\
\text { transaksi perdagangan atau barter } \\
\text { (TP1) }\end{array}$ & $\begin{array}{l}\text { Transaksi barter atau pertukaran } \\
\text { barang/jasa dengan seorang teman } \\
\text { tidak saya laporkan pada SPT. }\end{array}$ \\
\hline $\begin{array}{l}\text { Tidak melaporkan pendapatan } \\
\text { tambahan yang berjumlah kecil (TP2) }\end{array}$ & $\begin{array}{l}\text { Saya melaporkan seluruh penghasilan } \\
\text { utama, tetapi tidak melaporkan } \\
\text { pendapatan tambahan yang jumlahnya } \\
\text { kecil }\end{array}$ \\
\hline $\begin{array}{l}\text { Tidak melaporkan pendapatan dari } \\
\text { pekerjaan yang dibayarkan secara tunai } \\
\text { (TP3) }\end{array}$ & $\begin{array}{l}\text { Pendapatan yang saya peroleh secara } \\
\text { tunai tidak saya laporkan dalam SPT }\end{array}$ \\
\hline $\begin{array}{l}\text { Tidak melaporkan pendapatan dari } \\
\text { investasi (TP4) }\end{array}$ & $\begin{array}{l}\text { Saya tidak melaporkan pendapatan } \\
\text { bunga dari investasi yang tidak dapat } \\
\text { ditemukan pemerintah }\end{array}$ \\
\hline \multicolumn{2}{|l|}{ Alasan perilaku tidak patuh pajak } \\
\hline $\begin{array}{l}\text { Membayar pajak lebih sedikit karena } \\
\text { orang berpenghasilan lebih tinggi tidak } \\
\text { membayar pajak (ATP1) }\end{array}$ & $\begin{array}{l}\text { Karena ada orang-orang berpenghasilan } \\
\text { tinggi yang tidak membayar pajak, maka } \\
\text { bukanlah suatu masalah jika saya } \\
\text { membayar pajak lebih sedikit dari yang } \\
\text { seharusnya dibayarkan. }\end{array}$ \\
\hline $\begin{array}{l}\text { Membayar pajak lebih sedikit karena } \\
\text { tarif pajak sudah tinggi (ATP2) }\end{array}$ & $\begin{array}{l}\text { Karena tarif pajak terlalu tinggi, maka } \\
\text { bukanlah suatu kecurangan serius jika } \\
\text { saya membayar pajak lebih sedikit dari } \\
\text { yang seharusnya dibayarkan. }\end{array}$ \\
\hline Kesempatan mengurangi pajak (ATP3) & $\begin{array}{l}\text { Karena adanya kesempatan mengurangi } \\
\text { pajak, maka saya tidak serius dalam } \\
\text { menghitung pajak. Tujuan utama saya } \\
\text { adalah meminimalkan pembayaran } \\
\text { pajak. }\end{array}$ \\
\hline
\end{tabular}

Memotong beban pajak untuk Saya mengurangi setoran pajak, dan memenuhi kebutuhan (ATP4) uangnya saya pakai untuk memenuhi kebutuhan saya yang lain.

Menahan sedikit pajak (ATP5) Saya mengurangi setoran pajak, karena sudah terlalu banyak pengeluaran pemerintah.

Mengurangi bagian pajak lain dengan Saat hak saya untuk memperoleh pemerintah tidak dapat menangkapnya keringanan pajak tidak diberikan (ATP6) pemerintah, maka saya akan mengurangi pembayaran saya di bagian pajak lain yang tidak diketahui pemerintah.

Mengurangi pajak karena tidak Saya mengurangi setoran pajak, karena merugikan siapapun (ATP7) hal ini tidak akan merugikan siapapun.

Mengurangi pajak karena kecilnya Saya mengurangi setoran pajak, karena risiko tertangkap (ATP8) saya tahu bahwa risiko tertangkap oleh pemerintah sangat kecil.

Kadang-kadang mengurangi setoran Saya pikir tidak masalah jika kadangpajak karena merasa sudah loyal (ATP9) kadang saya mengurangi setoran pajak, karena saya adalah warga negara yang loyal dan patuh aturan.

Sumber: Yankelovich et al., (1984) dalam Gilligan dan Richardson (2005) 


\section{Metode Analisis}

Mengacu pada penelitian sebelumnya (Gilligan dan Richardson, 2005), penelitian ini bermaksud mendeskripsikan persepsi keadilan pajak pada dimensi keadilan umum, timbal balik pemerintah, ketentuan-ketentuan khusus, struktur tarif pajak, kepentingan pribadi dan kepatuhan pajak pada wajib pajak pengusaha dan pekerja di kota Salatiga.

\section{Tahapan Analisis}

Tahap-tahap analisis dari penelitian ini adalah sebagai berikut : (1) Mengumpulkan data melalui kuesioner dari wajib pajak pengusaha dan pekerja di kota Salatiga; (2) Melakukan uji validitas dan reliabilitas; (3) Mengolah data yang telah terkumpul dengan melakukan pengujian statistik deskriptif dan uji-t menggunakan aplikasi SPSS; (4) Menampilkan hasil dari pengolahan data dalam bentuk tabel untuk mempermudah dalam memberikan kesimpulan, yang berisi: (a) Analisis statistik deskriptif dan uji-t variabel-variabel penelitian; (b) Mendeskripsikan indikatorindikator persepsi keadilan dan kepatuhan pajak untuk masing-masing kelompok wajib pajak; (5) Menyusun kesimpulan dari hasil yang telah didapat mengenai persepsi keadilan dan kepatuhan pajak pada wajib pajak pengusaha dan pekerja di kota Salatiga.

Kriteria range yang hendak di tetapkan dalam penelitian ini sebanyak lima klasifikasi yang dipaparkan pada Tabel 4.

\section{Tabel 4. Kriteria range pengukuran skor}

\begin{tabular}{|c|c|c|c|}
\hline \multirow{3}{*}{ Skor } & \multicolumn{3}{|c|}{ Kriteria range } \\
\hline & \multirow[b]{2}{*}{ Keadilan pajak } & \multicolumn{2}{|c|}{ Kepatuhan pajak } \\
\hline & & $\begin{array}{c}\text { Perilaku tidak } \\
\text { patuh pajak }\end{array}$ & $\begin{array}{c}\text { Alasan perilaku } \\
\text { tidak patuh pajak }\end{array}$ \\
\hline $1,00-1,80$ & Sangat tidak adil & Sangat tidak patuh & Sangat tidak setuju \\
\hline $1,81-2,60$ & Tidak adil & Tidak patuh & Tidak setuju \\
\hline $2,61-3,40$ & Ragu-ragu & Ragu-ragu & Ragu-ragu \\
\hline $3,41-4,20$ & Adil & Patuh & Tidak setuju \\
\hline $4,21-5,00$ & Sangat adil & Sangat patuh & Sangat tidak setuju \\
\hline
\end{tabular}

\section{Hasil dan Pembahasan}

\section{Objek Penelitian}

Statistik deskriptif responden dalam penelitian dilihat melalui usia, jenis kelamin, pendidikan terakhir dan pernah/tidaknya mengikuti pendidikan informal dibidang perpajakan. Penelitian dilakukan dengan menyebarkan 82 kuesioner kepada wajib pajak pengusaha dan pekerja di kota Salatiga. Dari 82 kuesioner yang disebar, sebanyak 77 (93,9\%) kuesioner kembali dan 60 (73 \%) kuesioner yang dapat diolah. 17 kuesioner tidak dapat diolah karena jawaban tidak lengkap dan penulisan jawaban yang tidak serius.

Dari data Tabel 1 jika dikelompokan berdasarkan umur untuk pengusaha didominasi oleh usia 40-59 tahun sebesar 67\% dan untuk pekerja didominasi oleh usia 30-39 tahun sebesar 47\%. Pengelompokan berdasarkan jenis kelamin didapat data 
pengusaha didominasi oleh laki-laki sebesar 90\%, begitu juga pekerja didominasi oleh laki-laki sebesar 53\%. Pengelompokan berdasarkan tingkat pendidikan terakhir untuk pengusaha didominasi dengan pendidikan terakhir SMA sebesar $57 \%$, berbeda dengan pekerja yang didominasi dengan pendidikan terakhir S1 sebesar 57\%. Pengelompokan berdasarkan pernah/tidaknya mengikuti pendidikan informal di bidang perpajakan 10 dari 30 pengusaha atau sebesar 33\% menjawab pernah, dan 13 dari 30 pekerja atau sebesar $43 \%$ menjawab pernah.

\section{Tabel 5. Ringkasan Data Responden}

\begin{tabular}{|c|c|c|c|c|}
\hline \multirow[b]{2}{*}{ Variabel } & \multicolumn{2}{|c|}{ Pengusaha } & \multicolumn{2}{|c|}{ Pekerja } \\
\hline & $\begin{array}{c}\text { Jumlah } \\
\text { Responden }\end{array}$ & $\begin{array}{c}\text { Persentase } \\
(\%)\end{array}$ & $\begin{array}{c}\text { Jumlah } \\
\text { Responden }\end{array}$ & $\begin{array}{c}\text { Persentase } \\
(\%)\end{array}$ \\
\hline \multicolumn{5}{|l|}{ Umur } \\
\hline$<20$ & 0 & 0 & 0 & 0 \\
\hline $20-29$ & 3 & 10 & 6 & 20 \\
\hline $30-39$ & 6 & 20 & 14 & 47 \\
\hline $40-59$ & 20 & 67 & 10 & 33 \\
\hline$>60$ & 1 & 3.3 & 0 & 0 \\
\hline Total & 30 & 100 & 30 & 100 \\
\hline \multicolumn{5}{|l|}{ Jenis kelamin } \\
\hline Laki-laki & 27 & 90 & 16 & 53 \\
\hline Perempuan & 3 & 10 & 14 & 47 \\
\hline Total & 30 & 100 & 30 & 100 \\
\hline \multicolumn{5}{|l|}{$\begin{array}{l}\text { Pendidikan } \\
\text { terakhir }\end{array}$} \\
\hline SD & 1 & 3.3 & 0 & 0 \\
\hline SMP & 6 & 20 & 0 & 0 \\
\hline SMA & 17 & 57 & 3 & 10 \\
\hline D3 & 0 & 0 & 3 & 10 \\
\hline S1 & 6 & 20 & 17 & 57 \\
\hline S2 & 0 & 0 & 7 & 23 \\
\hline S3 & 0 & 0 & 0 & 0 \\
\hline Total & 30 & 100 & 30 & 100 \\
\hline $\begin{array}{l}\text { Pendidikan } \\
\text { informal } \\
\text { bidang } \\
\text { perpajakan }\end{array}$ & & & & \\
\hline Pernah & 10 & 33 & 13 & 43 \\
\hline Tidak & 20 & 67 & 17 & 57 \\
\hline Total & 30 & 100 & 30 & 100 \\
\hline
\end{tabular}

Sumber: Data Primer Diolah, 2018

\section{Statistik Deskriptif}

Berdasarkan hasil dari statistik deskriptif dimensi keadilan umum dengan melihat mean diperoleh informasi bahwa kelompok pengusaha menganggap adil pada dua indikator pembayaran pajak kelompok ekonomi menengah kebawah dan beban pajak masyarakat ekonomi menengah kebawah dengan skor masing-masing 3,47 dan 3,57. Serta menganggap tidak adil pada lima indikator, sistem pajak bagi masyarakat umum, sistem pajak bagi individu, sistem cara pendistribusian perhitungan pajak antar kelompok, beban pajak yang ditanggung secara individu dan pendistribusian beban pajak antar kelompok wajib pajak. 
Tabel 6. Statistik Deskriptif Dimensi Keadilan Umum

\begin{tabular}{|c|c|c|c|c|c|c|c|c|c|c|}
\hline & \multicolumn{5}{|c|}{ Pengusaha } & \multicolumn{5}{|c|}{ Pekerja } \\
\hline & Min & Max & Mean & Stdev & Kategori & Min & Max & Mean & Stdev & Kategori \\
\hline KU1 & 2 & 4 & 2,23 & 0,43 & $\begin{array}{c}\text { Tidak } \\
\text { adil }\end{array}$ & 1 & 4 & 2,30 & 0,54 & Tidak adil \\
\hline KU2 & 2 & 4 & 2,20 & 0,48 & $\begin{array}{c}\text { Tidak } \\
\text { adil }\end{array}$ & 1 & 4 & 2,37 & 0,81 & Tidak adil \\
\hline KU3 & 1 & 4 & 2,47 & 0,86 & $\begin{array}{c}\text { Tidak } \\
\text { adil }\end{array}$ & 2 & 4 & 2,53 & 0,86 & Tidak adil \\
\hline KU4 & 1 & 4 & 2,43 & 0,77 & $\begin{array}{c}\text { Tidak } \\
\text { adil }\end{array}$ & 2 & 4 & 3,50 & 0,78 & Adil \\
\hline KU5 & 2 & 4 & 2,37 & 0,67 & $\begin{array}{c}\text { Tidak } \\
\text { adil }\end{array}$ & 2 & 4 & 2,47 & 0,73 & Tidak adil \\
\hline KU6 & 2 & 4 & 3,47 & 0,77 & Adil & 2 & 5 & 3,53 & 1,04 & Adil \\
\hline KU7 & 2 & 5 & 3,57 & 0,90 & Adil & 2 & 5 & 3,63 & 0,85 & Adil \\
\hline
\end{tabular}

Namun, kelompok pekerja menganggap adil pada tiga indikator yaitu beban pajak yang ditanggung secara individu dengan skor 3,50, pembayaran pajak kelompok ekonomi menengah kebawah dengan skor 3,53 dan beban pajak masyarakat ekonomi menengah kebawah dengan skor 3,63. Serta menganggap tidak adil pada empat indikator sistem pajak bagi masyarakat umum, sistem pajak bagi individu, sistem cara pendistribusian perhitungan pajak antar kelompok dan pendistribusian beban pajak antar kelompok wajib pajak.

Kelompok pengusaha dan pekerja memiliki persamaan persepsi menganggap bahwa sistem perpajakan di Indonesia tidak adil baik secara umum maupun secara individu, sama halnya dengan sistem cara pendistribusian perhitungan pajak maupun pendistribusian beban pajak antar kelompok wajib pajak. Persepsi ketidakadilan dapat dipicu karena adanya isu korupsi di Direktorat Jenderal Pajak dan ketidakpuasan masyarakat atas pelayanan dan mekanisme pajak. Seperti penelitian McGee (2009) dalam (Wicaksono, 2014) mengaitkan sistem perpajakan dengan tarif pajak dan kemungkinan korupsi. Gambaran mengenai sistem pajak yaitu mengenai tinggi rendahnya tarif pajak dan kemanakah iuran pajak yang terkumpul, apakah benar-benar digunakan untuk pengeluaran umum, ataukah justru dikorupsi oleh pemerintah maupun oleh para petugas pajak, memiliki peran penting bagi wajib pajak dalam mengambil keputusan akan membayar atau tidak membayar pajak mereka.

Pada dimensi keadilan umum dari pernyataan kelompok pengusaha dan pekerja terdapat perbedaan persepsi pada indikator beban yang ditanggung. Pengusaha menganggap beban yang mereka tanggung tidak adil namun pekerja menganggap adil, dikonfirmasi dari uji-t perbedaan tersebut bersifat signifikan $(t=-5,33, p<0,00)$. Timbulnya perbedaan persepsi dapat terjadi karena pembebanan pajak menggunakan perhitungan penghasilan bruto bagi pengusaha penghasilan kurang dari 4,8M/tahun dengan tarif $1 \%$. Peraturan tarif $1 \%$ sekilas terlihat memudahkan, namun terdapat potensi ketidakadilan karena marjin setiap pengusaha berbeda-beda (Syahdan, 2014). Keadaan ini menimbulkan persepsi ketidak sebandingan pembebanan pajak dengan pendapatan dan menimbulkan persepsi bahwa sistem pajak yang berlaku memberatkan dan tidak adil. 
Tabel 7. Statistik Deskriptif Dimensi Timbal Balik Pemerintah

\begin{tabular}{|c|c|c|c|c|c|c|c|c|c|c|}
\hline & \multicolumn{5}{|c|}{ Pengusaha } & \multicolumn{5}{|c|}{ Pekerja } \\
\hline & Min & Max & Mean & Stdev & Kategori & Min & Max & Mean & Stdev & Kategori \\
\hline ТВ1 & 1 & 4 & 2,33 & 0,84 & $\begin{array}{c}\text { Tidak } \\
\text { adil }\end{array}$ & 2 & 4 & 2,50 & 0,77 & $\begin{array}{c}\text { Tidak } \\
\text { adil }\end{array}$ \\
\hline ГВ2 & 2 & 4 & 2,43 & 0,77 & $\begin{array}{c}\text { Tidak } \\
\text { adil }\end{array}$ & 2 & 4 & 2,47 & 0,82 & $\begin{array}{c}\text { Tidak } \\
\text { adil }\end{array}$ \\
\hline TB3 & 1 & 4 & 2,50 & 0,87 & $\begin{array}{c}\text { Tidak } \\
\text { adil }\end{array}$ & 2 & 4 & 2,53 & 0,86 & $\begin{array}{c}\text { Tidak } \\
\text { adil }\end{array}$ \\
\hline
\end{tabular}

Berdasarkan hasil dari statistik deskriptif dimensi timbal balik pemerintah dengan melihat mean diperoleh informasi bahwa kelompok pengusaha maupun pekerja menganggap tidak adil pada semua indikator yang dilihat dari kewajaran manfaat timbal balik, keadilan manfaat timbal balik serta perbandingan besar pajak dan manfaat timbal balik dengan skor rata-rata 2,42 untuk pengusaha dan 2,50 untuk pekerja. Kelompok pengusaha dan pekerja merasa manfaat dari timbal balik pemerintah yang mereka terima tidak wajar dan tidak adil, serta merasa manfaat yang mereka terima tidak sesuai jika dibandingkan dengan besarnya pajak penghasilan yang mereka bayarkan.

Pada dimensi timbal balik pemerintah secara umum baik kelompok pengusaha maupun pekerja tidak memiliki perbedaan pernyataan pada semua indikator. Persamaan persepsi kedua kelompok pengusaha dan pekerja yang menyatakan tidak adil atas timbal balik pemerintah dapat terjadi karena dalam proses pembayaran pajak mereka merasa tidak memperoleh timbal balik secara maksimal dari pajak yang mereka bayarkan (Hanum, 2005). Masyarakat merasa kurang puas terhadap penyediaan layanan publik yang diberikan oleh pemerintah, bahkan program yang dibuat pemerintah pun tidak dirasakan maksimal seperti program kesehatan BPJS dan e-KTP (Liando, 2016). Faktor lain yang dapat mempengaruhi persepsi kelompok pengusaha dan pekerja adalah fenomena tidak adanya transparansi pemerintah mengenai bagaimana uang pajak dikelola dan pendistribusian kepada masyarakat. Penelitian Wulandari (2017) menyatakan hal yang serupa bahwa masyarakat merasa pemerintah belum transparan mengenai bagaimana mengelola uang pajak serta hasil-hasil apa saja yang telah dicapai pemerintah untuk pembangunan. Fenomena tidak adanya transparansi pemerintah dapat membuat masyarakat merasa adanya kesenjangan kepentingan antara fiskus sebagai pihak yang diuntungkan dalam proses penerimaan pajak, dan selalu berusaha untuk mencapai target pemasukan ke dalam kas negara sebesar besarnya. Di lain pihak, masyarakat sebagai pihak yang harus membayar pajak tanpa mendapatkan pengembalian jasa secara langsung dari pembayaran yang dilakukannya (Ayu dan Hastuti, 2009). 
Tabel 8. Statistik Deskriptif Dimensi Ketentuan-Ketentuan Khusus

\begin{tabular}{ccccccccccc}
\hline & \multicolumn{4}{c}{ Pengusaha } & \multicolumn{5}{c}{ Pekerja } \\
\cline { 2 - 10 } & Min & Max & Mean & Stdev & Kategori & Min & Max & Mean & Stdev & Kategori \\
\hline KK1 & 1 & 3 & 2,23 & 0,77 & $\begin{array}{c}\text { Tidak } \\
\text { adil }\end{array}$ & 1 & 4 & 2,27 & 0,69 & $\begin{array}{c}\text { Tidak } \\
\text { adil }\end{array}$ \\
KK2 & 1 & 5 & 2,30 & 0,84 & $\begin{array}{c}\text { Tidak } \\
\text { adil }\end{array}$ & 1 & 4 & 2,37 & 0,67 & $\begin{array}{c}\text { Tidak } \\
\text { adil }\end{array}$ \\
& & & & & & & & & Tidak \\
KK3 & 2 & 4 & 2,47 & 0,77 & 2 & 4 & 3,47 & 0,90 & Adil \\
KK4 & 2 & 5 & 3,43 & 0,86 & Adil & 2 & 5 & 3,50 & 0,90 & Adil \\
\hline
\end{tabular}

Berdasarkan hasil dari statistik deskriptif dimensi ketentuan-ketentuan khusus dengan melihat mean diperoleh informasi bahwa kelompok pengusaha menganggap adil pada indikator kelonggaran pajak bagi masyarakat tidak mampu dengan skor 3,43 . Serta menganggap tidak adil pada indikator ketentuan khusus bagi wajib pajak tertentu, ketentuan khusus bagi wajib pajak penghasilan tinggi dan perbandingan dengan wajib pajak berpenghasilan lebih tinggi. Kelompok pengusaha menganggap bahwa ketentuan khusus berupa kelonggaran pajak bagi masyarakat tidak mampu merupakan ketentuan yang adil.

Namun, kelompok pengusaha menganggap bahwa ketentuan khusus yang hanya dapat digunakan oleh wajib pajak tertentu atau masyarakat penghasilan tinggi merupakan ketentuan yang tidak adil, dan ketika dibandingkan dengan masyarakat yang berpenghasilan lebih tinggi kelompok pengusaha merasa membayar lebih dari porsi seharusnya. Kelompok pekerja menganggap adil pada indikator perbandingan dengan wajib pajak berpendapatan lebih tinggi dengan skor 3,47 dan kelonggaran pajak bagi masyarakat tidak mampu dengan skor 3,50. Serta, menganggap tidak adil pada indikator ketentuan khusus bagi wajib pajak tertentu dan ketentuan khusus bagi wajib pajak penghasilan tinggi. Kelompok pekerja merasa adanya kewajaran ketika mereka membandingkan besarnya pajak yang mereka bayarkan dengan pekerja yang memiliki penghasilan lebih tinggi dan menganggap bahwa ketentuan khusus berupa kelonggaran bagi masyarakat tidak mampu adalah ketentuan yang adil. Namun, menganggap ketentuan khusus bagi wajib pajak tertentu atau wajib pajak penghasilan tinggi merupakan ketentuan yang tidak adil.

Persamaan persepsi kelompok pengusaha dan pekerja yang menganggap ketentuan khusus berupa kelonggaran bagi masyarakat tidak mampu adalah adil, karena ketentuan tersebut sebagai cerminan bahwa pemerintah melindungi masyarakat tidak mampu. Dalam memenuhi kebutuhanya kemampuan masyarakat tidak mampu masih rendah, jika dikenakan pajak akan lebih menyulitkan perekonomiannya. Bahkan, ketika tidak dapat membayar pajak dan dikenakan sanksi akan lebih memberatkan dan dirasa tidak adil. Namun, ketentuan khusus bagi wajib pajak tertentu atau wajib pajak penghasilan tinggi merupakan ketentuan yang tidak adil, karena ketentuan khusus yang ada hanya dapat digunakan oleh wajib pajak tertentu dan membuat gap antar wajib pajak. Penelitian Berutu dan Hartono (2012) menyatakan gap antar wajib pajak mengenai ketentuan khusus yang hanya dapat digunakan oleh wajib pajak tertentu dapat memicu paradigma bahwa ketentuanketentuan khusus yang berlaku tidak adil. 
Pada dimensi ketentuan-ketentuan khusus dari pernyataan kelompok pengusaha dan pekerja terdapat perbedaan persepsi pada indikator perbandingan dengan wajib pajak berpenghasilan lebih tinggi, yaitu pengusaha menganggap tidak adil namun pekerja menganggap adil. Dikonfirmasi dari uji-t perbedaan tersebut bersifat signifikan $(\mathrm{t}=-3.82, \mathrm{p}<0.00)$. Timbulnya perbedaan persepsi dapat terjadi karena perbedaan peraturan dan ketentuan perhitungan pajak penghasilan antar kelompok pengusaha dan pekerja. Peraturan pemerintah nomor 46 tahun 2013 menetapkan pengusaha dengan omset $<4,8 \mathrm{M} /$ tahun dasar pengenaan perhitungan pajak menggunakan pendapatan bruto. Namun, pengusaha dengan penghasilan > 4,8M/tahun dasar pengenaan pajaknya menggunakan penghasilan neto, bahkan adanya ketentuan khusus seperti fasilitas pengurangan tarif. Perbedaan ketentuan yang ada membuat persepsi bahwa jika dibandingkan dengan wajib pajak berpenghasilan lebih tinggi sepertinya tidak ada kesembandingan. Sedangkan kelompok pekerja dasar perhitungan pajaknya menggunakan peraturan pajak penghasilan pasal 17 dengan tarif progresif yang mencerminkan keadilan sesuai dengan kemampuan membayar. Wajib pajak yang memiliki kemampuan lebih akan dikenakan tarif dan beban pajak lebih besar sesuai tambahan penghasilan dengan peraturan yang ada dirasa adil oleh kelompok pekerja.

Tabel 9. Statistik Deskriptif Dimensi Struktur Tarif Pajak

\begin{tabular}{ccccccccccc}
\hline & \multicolumn{9}{c}{ Pengusaha } & \multicolumn{5}{c}{ Pekerja } \\
\cline { 2 - 10 } & Min & Max & Mean & Stdev & Kategori & Min & Max & Mean & Stdev & Kategori \\
\hline ST1 & 2 & 5 & 4,10 & 0,66 & Adil & 3 & 5 & 4,17 & 0,46 & Adil \\
ST2 & 3 & 5 & 4,03 & 0,56 & Adil & 2 & 5 & 3,93 & 0,74 & Adil \\
ST3 & 1 & 5 & 2,43 & 0,97 & Tidak & 1 & 5 & 2,37 & 1,10 & Tidak \\
ST4 & 2 & 4 & 3,47 & 0,73 & Adil & 2 & 5 & 3,43 & 0,68 & adil \\
\hline
\end{tabular}

Berdasarkan hasil dari statistik deskriptif dimensi struktur tarif pajak dengan melihat mean diperoleh informasi bahwa kelompok pengusaha menganggap adil pada indikator kemampuan membayar dengan skor 4,10, tarif progresif dengan skor 4,03 dan pembayaran pajak bagi masyarakat penghasilan tinggi dengan skor 3,47 . Begitu pula dengan kelompok pekerja menganggap adil pada indikator kemampuan membayar dengan skor 4,17, tarif progresif dengan skor 3,93 dan pembayaran pajak bagi masyarakat penghasilan tinggi dengan skor 3,43. Namun, baik kelompok pengusaha atau pekerja menganggap tidak adil pada indikator tarif pajak proposional. Pengusaha dan pekerja menganggap struktur tarif pajak yang adil adalah tarif pajak yang dikenakan berdasarkan kemampuan membayar dengan menggunakan struktur tarif pajak progresif. Dengan tarif pajak progresif wajib pajak penghasilan tinggi membayar dan dikenakan tarif pajak lebih tinggi dibanding wajib pajak penghasilan rendah. Berbeda dengan struktur tarif pajak proporsional wajib pajak penghasilan tinggi dikenakan tarif pajak yang sama dengan wajib pajak penghasilan rendah, sehingga kelompok pengusaha dan pekerja menganggap struktur tarif pajak proporsional tidak adil.

Pada dimensi struktur tarif pajak kelompok pengusaha maupun pekerja tidak memiliki perbedaan pernyataan pada semua indikator, hal ini dikonfirmasi dari uji-t yang menunjukan bahwa tidak ada perbedaan yang signifikan. Persamaan persepsi 
kedua kelompok pengusaha dan pekerja timbul karena struktur tarif pajak progresif mencerminkan asas keadilan vertikal, yaitu orang-orang dengan tambahan kemampuan ekonomi dikenakan pajak penghasilan yang berbeda setara dengan tambahan kemampuan ekonomi (Rahman, 2013). Prinsip keadilan vertikal berarti bahwa masyarakat yang mempunyai penghasilan lebih besar harus membayar pajak lebih besar dan masyarakat dalam kondisi ekonomi yang sama maka akan dikenakan pajak yang sama. Penelitian Nugroho (2014) juga menyatakan bahwa dengan struktur tarif pajak progresif terjadi pemerataan pembayaran pajak dan sebagai cerminan pengenaan pajak berdasarkan kemampuan membayar (ability to pay).

Kelompok pengusaha dan pekerja menganggap struktur tarif pajak proporsional tidak adil, meskipun struktur tarif pajak proporsional mencerminkan keadilan horizontal yaitu seluruh penghasilan dikenakan pajak dengan tarif yang sama tanpa membedakan jenis atau sumber penghasilan. Namun, struktur tarif pajak proporsional tidak mencerminkan konsep kemampuan membayar, dan keadilan yang terdapat pada struktur tarif pajak proporsional hanya bagi orang yang mempunyai penghasilan sama. Bagi wajib pajak yang mempunyai penghasilan berbeda dirasa struktur tarif pajak proporsional tidak adil karena wajib pajak dengan penghasilan tinggi dikenakan tarif pajak yang sama dengan wajib pajak penghasilan rendah hal ini tidak sesuai dengan konsep keadilan vertikal (Carolina et al., 2013).

Tabel 10. Statistik Deskriptif Dimensi Kepentingan Pribadi

\begin{tabular}{ccccccccccc}
\hline & \multicolumn{9}{c}{ Pengusaha } & \multicolumn{6}{c}{ Pekerja } \\
\cline { 2 - 11 } & Min & Max & Mean & Stdev & Kategori & Min & Max & Mean & Stdev & Kategori \\
\hline KP1 & 2 & 5 & 3,57 & 0,86 & Adil & 1 & 5 & 3,50 & 0,86 & Adil \\
KP2 & 1 & 5 & 2,57 & 0,94 & Tidak & 2 & 4 & 3,47 & 0,86 & Adil \\
KP3 & 2 & 5 & 3,43 & 0,77 & Adil & 2 & 4 & 3,47 & 0,82 & Adil \\
\hline
\end{tabular}

Berdasarkan hasil dari statistik deskriptif dimensi kepentingan pribadi dengan melihat mean diperoleh informasi bahwa kelompok pengusaha menganggap adil pada indikator keadilan pribadi dengan skor 3,57 dan perbandingan pembayaran pajak dengan wajib pajak penghasilan sama dengan skor 3,43. Namun, menganggap tidak adil pada indikator jumlah pajak yang dibayarkan. Sedangkan, kelompok pekerja menganggap adil pada semua indikator kepentingan pribadi mengenai keadilan pribadi, jumlah pajak yang dibayarkan dan perbandingan dengan wajib pajak penghasilan sama.

Kelompok pengusaha dan pekerja menganggap sistem pajak yang berlaku saat ini adalah sistem yang paling baik dalam mengumpulkan penerimaan negara sebagai keadilan pribadi. Ketika mereka membandingkan besarnya pajak yang dibayarkan dengan wajib pajak lain yang memiliki penghasilan sama mereka merasa adanya kesebandingan pembayaran beban pajak. Persamaan persepsi kedua kelompok dikarenakan pajak adalah sesuatu yang tidak dapat dihindari yang sifatnya memaksa dan wajib, disertai adanya sanksi yang mengikat ketika tidak dilaksanakan dengan patuh. Dengan peraturan dan ketentuan pajak yang berlaku mendorong wajib pajak untuk membayar pajak sebagai penerimaan negara terlepas dari motivasi setiap wajib pajak. Meskipun dalam peraturan pajak yang berlaku adanya ketentuan yang membuat gap antar wajib pajak, namun ketika pengusaha dan pekerja 
membandingkan pajak yang mereka bayarkan dengan wajib pajak yang memiliki penghasilan sama mereka merasa adanya kesebandingaan dengan dikenakan tarif yang sama tanpa membedakan jenis atau sumber penghasilan.

Pada dimensi kepentingan pribadi dari pernyataan kelompok pengusaha dan pekerja terdapat perbedaan persepsi pada indikator jumlah pajak yang dibayarkan, pengusaha menganggap peraturan perpajakan saat ini menuntutnya membayar lebih dari porsi seharusnya namun pekerja menganggap sebaliknnya. Dikonfirmasi dari ujit perbedaan tersebut bersifat signifikan $(t=-3,88, p<0,00)$. Kondisi ini terjadi karena perubahan ketentuan pajak yang berlaku sejak tahun 2013, yaitu peraturan pemerintah nomor 46 tahun 2013 yang menetapkan bahwa wajib pajak pengusaha yang memiliki penghasilan $<4,8 \mathrm{M} /$ tahun dikenakan pajak final $1 \%$ dengan dasar perhitungan penghasilan bruto.

Berbeda dengan Undang-Undang Republik Indonesia nomor 36 tahun 2008 wajib pajak yang melakukan usaha dengan penghasilan $<4,8 \mathrm{M} /$ tahun boleh menghitung penghasilan neto dengan menggunakan norma penghitungan penghasilan neto. Dengan tarif $1 \%$ terlihat kecil dari peraturan pajak sebelumnya, namun dengan perhitungan menggunakan peredaran bruto tarif $1 \%$ masih belum adil terutama bagi wajib pajak yang memiliki penghasilan neto yang rendah. Mungkin untuk beberapa pengusaha yang memiliki penghasilan neto tinggi akan menguntungkan, namun tidak semua pengusaha memiliki penghasilan neto yang tinggi. Peraturan tarif $1 \%$ tersebut membuat pengusaha menyatakan bahwa tarif pajak final $1 \%$ seharusnya lebih kecil (Ananda et al,. 2015) dan pengusaha merasa bahwa tarif final sebesar 1\% dari omset masih terlalu tinggi dan memberatkan wajib pajak (Miratusholihah et al., (2014). 
Tabel 11. Statistik Deskriptif Kepatuhan pajak

\begin{tabular}{|c|c|c|c|c|c|c|c|c|c|c|}
\hline & \multicolumn{5}{|c|}{ Pengusaha } & \multicolumn{5}{|c|}{ Pekerja } \\
\hline & Min & Max & Mean & Stdev & Kategori & Min & Max & Mean & Stdev & Kategori \\
\hline \multicolumn{11}{|c|}{ Perilaku tidak patuh pajak (TP) } \\
\hline TP1 & 2 & 5 & 2,37 & 0,80 & $\begin{array}{l}\text { Tidak } \\
\text { patuh }\end{array}$ & 2 & 4 & 2,43 & 0,63 & $\begin{array}{l}\text { Tidak } \\
\text { patuh }\end{array}$ \\
\hline TP2 & 2 & 4 & 2,47 & 0,78 & $\begin{array}{l}\text { Tidak } \\
\text { patuh }\end{array}$ & 2 & 4 & 2,57 & 0,8 & $\begin{array}{l}\text { Tidak } \\
\text { patuh }\end{array}$ \\
\hline TP3 & 2 & 4 & 3,40 & 0,68 & $\begin{array}{l}\text { Tidak } \\
\text { patuh }\end{array}$ & 2 & 4 & 3,63 & 0,73 & Patuh \\
\hline TP4 & 1 & 4 & 2,50 & 0,73 & Patuh & 2 & 5 & 3,50 & 0,73 & Patuh \\
\hline \multicolumn{11}{|c|}{ Alasan perilaku tidak patuhan pajak (ATP) } \\
\hline ATP1 & 3 & 4 & 3,77 & 0,43 & $\begin{array}{l}\text { Tidak } \\
\text { setuju }\end{array}$ & 2 & 4 & 3,53 & 0,68 & $\begin{array}{c}\text { Tidakset } \\
\text { uju }\end{array}$ \\
\hline ATP2 & 2 & 5 & 3,53 & 0,90 & $\begin{array}{l}\text { Tidak } \\
\text { setuju }\end{array}$ & 2 & 5 & 3,63 & 0,85 & $\begin{array}{l}\text { Tidak } \\
\text { setuju }\end{array}$ \\
\hline ATP3 & 2 & 4 & 2,50 & 0,86 & Setuju & 2 & 5 & 3,70 & 0,84 & $\begin{array}{c}\text { Tidakset } \\
\text { uju }\end{array}$ \\
\hline ATP4 & 2 & 4 & 3,47 & 0,90 & $\begin{array}{l}\text { Tidak } \\
\text { setuju }\end{array}$ & 1 & 5 & 3,80 & 0,85 & $\begin{array}{l}\text { Tidak } \\
\text { setuju }\end{array}$ \\
\hline ATP5 & 2 & 5 & 3,60 & 0,72 & $\begin{array}{l}\text { Tidak } \\
\text { setuju }\end{array}$ & 3 & 5 & 3,83 & 0,60 & $\begin{array}{c}\text { Tidakset } \\
\text { uju }\end{array}$ \\
\hline ATP6 & 2 & 5 & 3,43 & 0,86 & $\begin{array}{l}\text { Tidak } \\
\text { setuju }\end{array}$ & 2 & 5 & 3,67 & 0,66 & $\begin{array}{l}\text { Tidak } \\
\text { setuju }\end{array}$ \\
\hline ATP7 & 2 & 5 & 3,57 & 0,86 & $\begin{array}{l}\text { Tidak } \\
\text { setuju }\end{array}$ & 2 & 5 & 3,77 & 0,68 & $\begin{array}{c}\text { Tidakset } \\
\text { uju }\end{array}$ \\
\hline ATP8 & 2 & 4 & 2,40 & 0,77 & Setuju & 2 & 5 & 3,93 & 0,58 & $\begin{array}{l}\text { Tidak } \\
\text { setuju }\end{array}$ \\
\hline ATP9 & 2 & 5 & 3,57 & 0,82 & $\begin{array}{l}\text { Tidak } \\
\text { setuju }\end{array}$ & 2 & 5 & 3,90 & 0,76 & $\begin{array}{l}\text { Tidak } \\
\text { setuju }\end{array}$ \\
\hline
\end{tabular}

Berdasarkan hasil dari statistik deskriptif kepatuhan pajak dengan melihat mean diperoleh informasi bahwa kelompok pengusaha patuh pada indikator pendapatan tunai dengan skor 3,40. Namun tidak patuh pada tiga indikator transaksi barter, pendapatan tambahan dan pendapatan investasi. Dengan pengenaan self assessment system bagi kelompok pengusaha dapat disalahgunakan seperti tidak melaporkan ke dalam SPT ketika adanya transaksi barter/pertukaran barang, pendapatan tambahan yang jumlahnya kecil dan pendapatan dari investasi. Dan ketika ada kesempatan untuk mengurangi pajak maka pengusaha tidak seriusan dalam menghitung pajak, dengan tujuan untuk meminimalkan pembayaran pajak.

Kelompok pekerja patuh pada dua indikator pendapatan tunai dengan skor 3,63 dan pendapatan investasi dengan skor 3,50. Dengan withholding tax system pekerja patuh terhadap peraturan perpajakan dengan membayar sesuai tarif pajak yang berlaku dan tidak memotong besarnya beban pajak yang ditangguhkan, karena dengan withholding tax system besarnya pajak yang ditangguhkan dihitung langsung oleh pemberi kerja. Namun, meskipun pada kelompok pekerja tingkat keputusan berperilaku patuh/tidak patuh kecil terdapat aspek perilaku tidak patuh dengan tidak melaporkan transaksi barter/pertukaran barang dan jasa serta pendapatan tambahan yang jumlahnya kecil pekerja tidak melaporkan ke dalam SPT.

Perbedaan kepatuhan antar kelompok wajib pajak pengusaha dengan self assessment system dan pekerja dengan withholding tax system. Dari perbedaan yang signifikan 
dapat disimpulkan bahwa kelompok pekerja dengan withholding tax system lebih patuh dibanding kelompok pengusaha dengan self assessment system. Penelitian sebelumnya yang mendukung pernyataan ini dilakukan oleh Pasaribu dan Tjen (2016) yang menyatakan bahwa wajib pajak yang bekerja sebagai pekerja lebih patuh dibandingkan dengan wajib pajak yang memiliki usaha sendiri (pengusaha). Kepatuhan antar kelompok pengusaha dan pekerja dapat dikaitkan dengan perhitungan pajak self assessment system bagi pengusaha dan withholding tax system bagi pekerja. Self assessment system memberikan wewenang wajib pajak untuk menentukan sendiri besarnya pajak yang terutang, berarti sebagian besar keputusan berperilaku patuh maupun tidak patuh ada di tangan wajib pajak. Sistem tersebut membuka peluang dilaksanakannya kecurangan-kecurangan dalam memenuhi kewajiban perpajakan (Hasan, 2008) dalam (Darmayani dan Herianti, 2017). Sedangkan, withholding tax system hanya sebagian kecil keputusan berperilaku patuh atau tidak patuh ada ditangan wajib pajak. Withholding tax system lebih menjamin kepastian pajak terbayar sebab yang memotong adalah pemberi penghasilan yang cenderung lebih disiplin (Darmayasa et al., 2016).

\section{Analisis Tambahan}

\section{Keadilan Umum}

Secara umum pada dimensi keadilan umum baik kelompok pengusaha maupun pekerja tidak terdapat perbedaan persepsi, dikonfirmasi dari uji-t tidak terdapat perbedaan yang signifikan $(\mathrm{t}=-0,61, \mathrm{p}<0,54)$. Kelompok pengusaha dan pekerja sama-sama masih ragu-ragu mengenai keadilan umum perpajakan di Indonesia, sebagaimana disajikan dalam Tabel 12 .

\section{Tabel 12. Uji Sampel Independen}

\begin{tabular}{cccc}
\hline & Mean difference & t & Sig \\
\hline Keadilan umum (KU) & $-0,34$ & $-0,61$ & 0,54 \\
KU1 & $-0,07$ & $-0,53$ & 0,60 \\
KU2 & $-0,17$ & $-0,97$ & 0,34 \\
KU3 & $-0,07$ & $-0,30$ & 0,77 \\
KU4 & $-1,07$ & $-5,33$ & 0,00 \\
KU5 & $-0,10$ & $-0,55$ & 0,58 \\
KU6 & $-0,07$ & $-0,28$ & 0,78 \\
KU7 & $-0,07$ & $-0,29$ & 0,77 \\
\hline
\end{tabular}

\section{Timbal Balik Pemerintah}

Secara umum pada dimensi timbal balik pemerintah baik kelompok pengusaha maupun pekerja tidak terdapat perbedaan persepsi, dikonfirmasi dari uji-t tidak terdapat perbedaan yang signifikan $(t=0,44, p<0,66)$. Kelompok pengusaha dan pekerja sama-sama menganggap bahwa timbal balik pemerintah tidak adil, pada Tabel 13. 
Tabel 13. Uji Sampel Independen

\begin{tabular}{cccc}
\hline & Mean difference & t & Sig \\
\hline Timbal balik pemerintah (TB) & $-0,08$ & 0,44 & 0,66 \\
TB1 & $-0,17$ & $-0,79$ & 0,43 \\
TB2 & $-0,03$ & $-0,16$ & 0,87 \\
TB3 & $-0,03$ & $-0,15$ & 0,88 \\
\hline
\end{tabular}

\section{Ketentuan-Ketentuan Khusus}

Secara umum pada dimensi ketentuan-ketentuan khusus antar kelompok pengusaha dan pekerja terdapat perbedaan persepsi, namun perbedaan tersebut tidak signifikan. Dikonfirmasi dari uji- $\mathrm{t}$ tidak terdapat perbedaan yang signifikan $(\mathrm{t}=-1,92$, $\mathrm{p}<0,60$ ). Kelompok pengusaha menganggap bahwa ketentuan-ketentuan khusus yang berlaku tidak adil dan kelompok pekerja masih ragu-ragu mengenai keadilan ketentuan-ketentuan khusus yang berlaku, disajikan pada Tabel 14 .

\section{Tabel 14. Uji Sampel Independen}

\begin{tabular}{cccc}
\hline & Mean difference & t & Sig \\
\hline Ketentuan-ketentuan khusus (KK) & $-0,29$ & $-1,92$ & 0,60 \\
KK1 & $-0,03$ & $-0,76$ & 0,86 \\
KK2 & $-0,6$ & $-0,34$ & 0,73 \\
KK3 & $-1,00$ & $-4,61$ & 0,00 \\
KK4 & $-0,67$ & $-0,29$ & 0,77 \\
\hline
\end{tabular}

\section{Struktur Tarif Pajak}

Secara umum pada dimensi struktur tarif pajak baik kelompok pengusaha maupun pekerja tidak terdapat perbedaan persepsi, dikonfirmasi dari uji-t tidak terdapat perbedaan yang signifikan $(t=0,27, p<0,79)$. Kelompok pengusaha dan pekerja sama-sama menganggap bahwa struktur tarif pajak dengan tarif progresif adalah struktur tarif pajak yang paling adil, Tabel 15.

\section{Tabel 15. Uji Sampel Independen}

\begin{tabular}{cccc}
\hline & Mean difference & t & Sig \\
\hline Struktur tarif pajak & 0,03 & 0,27 & 0,79 \\
ST1 & $-0,07$ & $-0,45$ & 0.65 \\
ST2 & 0,10 & 0,59 & 0,56 \\
ST3 & 0,07 & 0,25 & 0,80 \\
ST4 & 0,03 & 0,18 & 0,86 \\
\hline
\end{tabular}

\section{Kepentingan Pribadi}

Secara umum pada dimensi kepentingan pribadi antar kelompok pengusaha dan pekerja adanya perbedaan persepsi, namun perbedaan tersebut tidak signifikan. Dikonfirmasi dari uji-t tidak terdapat perbedaan yang signifikan $(t=-1,89, p<0,06)$, Tabel 16. Kelompok pengusaha ragu-ragu mengenai keadilan kepentingan pribadi dan kelompok pekerja merasa adanya keadilan pada kepentingan pribadi. 
Tabel 16. Uji Sampel Independen

\begin{tabular}{cccc}
\hline & Mean difference & t & Sig \\
\hline Kepentingan pribadi & $-0,31$ & $-1,89$ & 0,06 \\
KP1 & 0,07 & 0,30 & 0,76 \\
KP2 & $-0,90$ & $-3,88$ & 0,00 \\
KP3 & $-0,10$ & $-0,49$ & 0,63 \\
\hline
\end{tabular}

\section{Kepatuhan Pajak}

Secara umum dapat disimpulkan bahwa wajib pajak pekerja lebih patuh dibandingkan kelompok wajib pajak pengusaha, ketika melihat aspek perilaku tidak patuh pajak. Dikonfirmasi dari uji-t adanya perbedaan yang signifikan perilaku kepatuhan kelompok pengusaha dan pekerja $(\mathrm{t}=-2,987, \mathrm{p}<0,04)$. Kelompok pengusaha memberikan alasan atas perilaku tidak patuh pajak yaitu karena adanya kesempatan mengurangi pajak dan resiko tertangkap oleh pemerintah yang sangat kecil. Sedangkan pada indikator alasan perilaku tidak patuh pajak, kelompok pekerja menyatakan tidak setuju pada semua indikator. Berarti, pada indikator perilaku tidak patuh pajak kelompok pekerja dikarenakan adanya alasan lain, yang mungkin seperti ketidaktahuan atau karena adanya faktor lingkungan sesama pekerja yang tidak membayar pajak.

Sebagaimana disajikan dalam Tabel 17.

\section{Tabel 17. Uji Sampel Independen}

\begin{tabular}{lccc}
\hline & Mean difference & t & Sig \\
\hline Perilaku tidak patuh pajak (TP) & 58 & $-2,987$ & 0,04 \\
TP1 & $-0,07$ & $-0,36$ & 0,72 \\
TP2 & $-0,10$ & $-0,49$ & 0,63 \\
TP3 & $-1,23$ & $-1,35$ & 0,18 \\
TP4 & $-1,00$ & $-5,30$ & 0,00 \\
Alasan perilaku tidak patuhan pajak & -0.44 & -3.33 & 0,00 \\
(ATP) & 0,23 & 1,59 & 0,12 \\
ATP1 & $-0,10$ & $-0,44$ & 0,66 \\
ATP2 & $-1,20$ & $-5,47$ & 0,00 \\
ATP3 & $-0,33$ & $-1,48$ & 0,14 \\
ATP4 & $-0,23$ & $-1,37$ & 0,18 \\
ATP5 & $-0,23$ & $-1,18$ & 0,24 \\
ATP6 & $-0,20$ & $-1,00$ & 0,32 \\
ATP7 & $-1,53$ & $-8,69$ & 0,00 \\
ATP8 & $-0,33$ & $-1,64$ & 0,11 \\
ATP9 & & & \\
\hline
\end{tabular}

\section{Simpulan}

Dari hasil penelitian dapat disimpulkan bahwa secara umum pada dimensi keadilan umum baik kelompok pengusaha maupun pekerja ragu-ragu mengenai keadilan umum sistem perpajakan yang berlaku, dan menganggap adanya ketidakadilan timbal balik pemerintah. Pada dimensi ketentuan-ketentuan khusus yang ditetapkan oleh pemerintah yang hanya dapat digunakan oleh wajib pajak tertentu, kelompok pengusaha menganggap tidak adil dan kelompok pekerja menganggap ragu-ragu mengenai keadilan ketentuan khusus yang berlaku. Dan pada dimensi struktur tarif pajak baik kelompok pengusaha maupun pekerja berpersepsi bahwa struktur tarif 
pajak yang adil adalah struktur tarif pajak yang dikenakan berdasarkan kemampuan membayar dengan menganggap tarif progresif adalah tarif yang paling adil. Serta pada dimensi kepentingan pribadi kelompok pengusaha menganggap ragu-ragu mengenai keadilan dimensi kepentingan pribadi, namun kelompok pekerja menganggap adil ketika mereka membandingkan jumlah pajak yang mereka bayarkan dengan besarnya jumlah pajak yang wajib pajak lain bayarkan. Dan secara umum tidak terdapat perbedaan yang signifikan persepsi antar kelompok pengusaha dan pekerja. Pada perilaku kepatuhan pajak dapat disimpulkan bahwa kelompok pekerja lebih patuh pajak dibanding kelompok pengusaha dengan pengenaan pajak with holding tax system.

Hasil dari penelitian ini menyatakan bahwa secara umum tidak terdapat perbedaan persepsi yang signifikan antar kelompok pengusaha dan pekerja pada dimensi keadilan umum, timbal balik pemerintah, ketentuan-ketentuan khusus, struktur tarif pajak dan kepentingan pribadi. Hasil ini sesuai dengan penelitian Berutu (2012) yang menyatakan bahwa baik pengusaha maupun pekerja sama-sama berpersepsi bahwa adanya ketidakadilan pajak. Pada perilaku kepatuhan pajak terdapat perbedaan yang signifikan antar kepatuhan kelompok pengusaha dan pekerja, yaitu kelompok pekerja lebih patuh pajak dibanding kelompok pengusaha. Hasil ini sesuai dengan penelitian Pasaribu dan Tjen (2016) yang menyatakan bahwa wajib pajak yang bekerja sebagai pekerja lebih patuh dibandingkan dengan wajib pajak yang memiliki usaha sendiri (pengusaha).

Penelitian ini dapat memberikan manfaat bagi DJP sebagai pertimbangan dalam membuat kebijakan upaya meningkatkan kepatuhan wajib pajak dengan memperhitungkan bagaimana persepsi keadilan pajak antar kelompok pengusaha dan pekerja. Hasil penelitian menunjukan bahwa kelompok pekerja dengan withholding tax system lebih patuh dibanding kelompok pengusaha dengan self assessment system. Dengan demikian DJP harus mengambil tindakan seperti pengawasan pajak yang lebih ketat terhadap kelompok pengusaha. Dan menetapkan kebijakan dengan memperhitungkan persepsi keadilan yang tidak membuat timpang pembebanan pajak namun menciptakan pemerataan pembebanan pajak.

Penelitian ini memiliki keterbatasan dalam pengambilan sampel belum memastikan apakah pekerja berpenghasilan > PTKP, tidak memastikan pengusaha/pekerja adalah murni pengusaha/pekerja dan hanya meneliti pengusaha yang mempunyai usaha skala kecil, serta tidak menganalisis pengusaha /pekerja sampai demografinya. Sehingga dalam pengambilan sampel tidak mengetahui kebenaran sampel pada pekerja apakah berpenghasilan > PTKP, dan juga kebenaran pengusaha/pekerja adalah murni pengusaha/pekerja yang tidak memiliki dua sumber penghasilan. Serta, persepsi yang termuat tidak bisa mewakili pengusaha skala besar, karena hanya diperoleh responden usaha skala kecil saja. Sehingga, saran dari penelitian ini ketika dalam pengambilan sampel memastikan terlebih dahulu apakah sampel benar-benar sesuai dengan kriteria yang diperlukan, serta memperluas profil pengusaha di berbagai kategori usaha dan menganalisis demografi untuk melihat persepsi keadilan dan kepatuhan pajak di berbagai aspek demografi. 


\section{Daftar Pustaka}

Ananda, Dwi, Rizki, Pasca, Srikandi Kusmandji, dan Achmand Husaini. 2015. "Pengaruh Sosiolisasi Perpajakan, Tarif Pajak, dan Pemahaman Perpajakan terhadap Kepatuhan Wajib Pajak (Studi pada UMKM yang Terdaftar Sebagai Wajib Pajak di Kantor Pelayanan Pajak Pratama Batu)." Jurnal Perpajakan (JEJAK) 6 (2).

Ayu, Dyah, Stephana, dan Rini Hastuti. 2009. "Persepsi Wajib Pajak: Dampak Pertentangan Diamentral pada Tax Evasion Wajib Pajak dalam Aspek Kemungkinan Terdeteksinya Kecurangan, Keadilan, Ketepatan Pengelokasian, Teknologi Sistem Perpajakan, dan Kecenderungan Personal (Studi Wajib Pajak Orang Pribadi)." Kajian Akuntansi 1 (1): 1-12.

Berutu, Dian Anggreani, dan Puji Hartono. 2012. "Persepsi Keadilan Pajak terhadap Perilaku Kepatuhan Wajib Pajak Orang Pribadi.” Diponegoro journal of accounting 2 (2): 1-10. http://ejournal-s1.undip.ac.id/index.php/accounting.

Carolina, Verani, Meyta, and Riki Martusa. 2013. "Tax Culture : Dasar Pelaksanaan Reformasi Perpajakan Menuju Kepatuhan Sukarela." Proceeding Simposium Nasional perpajakan III "Road map reformasi perpajakan Indonesia menuju godd governance".

Darmayani, Diera, dan Eva Herianti. 2017. "Pengaruh Tingkat Kepatuhan Wajib Pajak Badan terhadap Peningkatan Penerimaan Pajak Penghasilan dengan Penagihan Pajak sebagai Variabel Moderating (Pada KPP Pratama Cilandak Jakarta Selatan)." Jurnal Infestasi 13 (1): 275-284.

Darmayasa, I Nyoman, Rizka, Yuyung Aneswari, dan Era, Elana Yusfita. 2016. "Meningkatkan Kepatuhan dan Penerimaan Pajak Melalui Withholding Tax System." Jurnal Infestasi 12 (2): 203-216.

Gerbing. 1988. "An Empirical Study of Taxpayer Perception of Fairness." Unpublished PhD thesis. University of Texas Ausin.

Gilligan, George, dan Grant Richardson. 2005. "Perceptions of Tax and Tax Compliance in Australia and Hongkong." Journal of Financial Crime 12 (4): 331-343.

Hanum, Noviani, Ayu. 2005. “Permasalahan Pajak Indonesia.” Value Added 2 (1).

Hardiningsih, Pancawati, dan Nila Yulianawati. 2011. "Faktor-Faktor yang Mempengaruhi Kemauan Membayar Pajak." Dinamika Keuangan dan Perbankan 3 (1): 126-142.

Kementrian Keuangan Republik Indonesia. 2017. Realisasi Anggaran Pendapatan dan Belanja Negara. https://www.kemenkeu.go.id/node/34644.

Liando, Daud. 2016. "Manajemen Rekrutmen Calon Pegawai Negeri Sipil dalam Hubungan dengan Kualitas Pelayanan Publik di Kota Manado." Jurnal Ilmu Sosial dan Pengelolaan Sumberdaya Pembangunan.

Miratusholihah. 2014. Pengaruh Pengetahuan Perpajakan, Kualitas Pelayanan Fiskus dan Tarif Pajak Terhadap Kepatuhan Wajib Pajak. Skripsi. Universitas Brawijaya 
Morissan. 2012. Metode Penelitian Survei. Jakarta: Prenadamedia Group. www.prenadamedia.com.

Nugroho, Stefani Galung Widorini and Joko purwanto. 2014. "Pengaruh Pengetahuan, Persepsi tentang Tarif Pajak dan Penegakan Hukum Perpajakan terhadap Kepatuhan Wajib Pajak Orang Pribadi di Kpp Pratama Yogyakarta." Jurnal Bisnis dan Ekonomi 5 (1): 85-98.

Pasaribu, Frisno, Ganda, dan Christine Tjen. 2016. "Dampak Faktor-Faktor Demografi terhadap Kepatuhan Perpajakan di Indonesia." Berkala Akuntansi dan Keuangan Indonesia 1 (2): 145-162.

Pris, Andarini. 2010. "Dampak Dimensi Keadilan Pajak terhadap Kepatuhan Wajib Pajak Badan." Skripsi. Universitas Diponegoro.

Prof. Drs. Sutrisno Hadi, MA. 2015. Metodologi Riset. Yogyakarta: Pustaka Pelajar.

Rahman, Irma Suryani. 2013. "Pengaruh Keadilan, Sistem Perpajakan, Diskriminasi, dan Kemungkinan Terdeteksi Kecurangan terhadap Persepsi Wajib Pajak Mengenai Etika Penggelapan Pajak (Tax Evasion)." Skripsi. Universitas Islam Negeri Syarif Hidayatullah.

Roscoe. 1975. Research Methods for Business. 7. Dialihbahasakan oleh Uma Sakaran dan Roger Bougie. A Skill Building Approach.

Sarjono, Haryadi, dan Winda Julianita. 2011. Spss Vs Lisrel (Sebuah Pengantar, Aplikasi Untuk Riset). Jakarta: Salemba Empat.

Suhendra, Euphrasia Susy. 2010. "Pengaruh Tingkat Kepatuhan Wajib Pajak Badan terhadap Peningkatan Penerimaan Pajak Penghasilan Badan.” Skripsi. Universitas Gunadarma.

Syahdan, Saifhul, Anuar. 2014. "Dimensi Keadilan Pemberlakuan Pp No. 46 Tahun 2013 dan Peningkatan Kepatuhan Wajib Pajak." Jurnal Infestasi 10 (1): 64-72.

Witono, Banu. 2008. "Peran Pengetahuan Pajak pada Kepatuhan Wajib Pajak." Jurnal Akuntansi dan Keuangan 7 (2): 196-208.

Wulandari, Soliyah. 2017. "Pengaruh Persepsi Keadilan Pajak dalam Peraturan Pemerintah Republik Indonesia Nomor 46 Tahun 2013 terhadap Kepatuhan dalam Memenuhi Kewajiban Perpajakan." Jurnal Ekonomi Islam 8 (2): 239 - 268.

Yankelovich, Skelly, And White Inc. 1984. "Survey of Tax Attitudes." Internal Revenue Service. 